Buletin Ilmiah Math. Stat. dan Terapannya (Bimaster)

Volume 08, No. 3 (2019), hal 627 - 632.

\title{
PENENTUAN CADANGAN PREMI ASURANSI JIWA DWIGUNA BERJANGKA DENGAN METODE ILLINOIS
}

\author{
Dwi Ayu Lestari, Neva Satyahadewi, Hendra Perdana
}

\begin{abstract}
INTISARI
Asuransi jiwa adalah asuransi yang bertujuan menanggung resiko-resiko orang terhadap kerugian finansial yang tak terduga yang disebabkan oleh kematian, kecelakaan atau mengalami cacat tetap. Perusahaan asuransi sebagai penanggung akan memberikan premi sebagai santunan apabila seseorang yang mengikuti asuransi mengalami kematian. Perusahaan harus menmpersiapkan dana sebagai cadangan premi untuk mengantisipasi kercugian bila di masa yang akan datang terjadi klaim. Cadangan premi ini nantinya akan digunakan untuk membayar uang pertanggungan apabila terjadi klaim. Penelitian ini bertujuan untuk menentukan besarnya cadangan yang diperoleh dengan menggunakan metode Illinois yang merupakan perluasan dari metode prospektif. Pada penelitian ini dilakukan studi kasus untuk seorang laki-laki berusia 20 tahun dengan jangka waktu pembayaran 20 tahun, dan masa asuransi 25 tahun. Santunan yang diberikan kepada tertanggung sebesar Rp100.000.000 dan suku bunga 5,75\%. Data yang digunakan yaitu Tabel Mortalita Indonesia tahun 2011. Nilai cadangan yang dihasilkan untuk tahun pertama sebesar Rp1.522.035. Nilai cadangan akan semakin besar setiap tahunnya selama masa pertanggungan hingga pada akhir masa pertanggungan akan bernilai sama dengan santunan yang diterima oleh tertanggung.
\end{abstract}

Kata Kunci: Premi, Cadangan, Metode Illinois, Cadangan Prospektif.

\section{PENDAHULUAN}

Salah satu risiko yang akan dialami oleh manusia adalah kematian. Risiko kematian akan terjadi kapan saja tanpa diketahui pasti kapan terjadinya. Apabila seseorang yang menghidupi suatu keluarga mengalami kematian, maka keluarga yang ditinggalkan tersebut akan mempunyai masalah ekonomi jika mereka tidak memiliki simpanan biaya yang cukup untuk kehidupan mereka. Perusahaan asuransi sebagai penanggung akan memberikan premi sebagai santunan apabila seseorang yang mengikuti asuransi mengalami kematian.

Asuransi jiwa adalah asuransi yang bertujuan menanggung resiko-resiko orang terhadap kerugian finansial yang tak terduga yang disebabkan oleh kematian, kecelakaan atau mengalami cacat tetap[1]. Dalam asuransi jiwa terdapat tiga subjek utama, yaitu penanggung, tertanggung, dan ahli waris. Asuransi jiwa juga dapat diartikan sebagai perjanjian antara penanggung dengan tertanggung yang mengharuskan tertanggung membayarkan premi dengan jumlah tertentu jika tertanggung mengalami kematian [2].

Pada saat tertentu perusahaan bisa saja mengalami kerugian ketika terdapat tertanggung yang meninggal dunia tetapi perusahaan tidak mempunyai dana, sedangkan perusahaan tersebut harus mengeluarkan sejumlah dana untuk santunan. Oleh karena itu, untuk mengantisipasi kerugian perusahaan maka sebagian dari premi yang diterima oleh perusahaan harus dicadangkan sebagai cadangan premi, sehingga bila di masa yang akan datang terjadi klaim maka perusahaan tidak kesulitan membayarnya. Cadangan premi ini nantinya digunakan untuk membayar uang pertanggungan apabila terjadi klaim. Cadangan premi perlu disesuaikan dan penyesuaian ini akan memungkinkan perusahaan mendapat sumber dana baru untuk menutupi biaya ditahun permulaan polis sehingga perusahaan asuransi tidak kesulitan untuk membayar.

Nilai cadangan premi asuransi jiwa berjangka dalam penelitian ini menggunakan metode Illinois yang merupakan perluasan dari metode prospektif. Metode Illinois membatasi biaya yang dibebankan pada peserta asuransi dengan batasan 20 tahun pembayaran. Penelitian ini bertujuan untuk mengkaji 
cadangan premi dengan menggunakan metode Illinois dan diberikan aplikasi numerik cadangan pada asuransi jiwa bersama dwiguna. Tingkat suku bunga yang akan digunakan yaitu 5,75\%, menggunakan Tabel Mortalita Indonesia tahun 2011.

Penentuan cadangan premi metode Illinois dimulai dari menentukan usia tertanggung $x$ tahun, lama masa pertanggungan selama $n$ tahun, lama masa pembayaran $h$ tahun, dan besar santunan yang dipilih. Selanjutnya, menghitung nilai asuransi, menghitung nilai anuitas dan menghitung nilai premi tahunan untuk produk asuransi jiwa dwiguna. Setelah itu, ditentukanlah nilai cadangan premi metode Illinois dari sebuah perusahaan.

\section{Premi Asuransi Jiwa Berjangka}

Asuransi dwiguna (endowment) $n$ tahun dengan jumlah unit pembayaran pada akhir tahun kematian adalah kombinasi dari asuransi berjangka $n$ tahun dan asuransi dwiguna murni (pure endowment) $n$ tahun. Hal ini berarti dalam maupun saat berakhirnya masa pertanggungan kepada pemegang polis, baik meninggal maupun bertahan hidup akan dibayarkan uang pertanggungan. Polis asuransi jiwa dwiguna menjanjikan pembayaran sejumlah uang bila terjadi kematian dalam jangka waktu atau bila tertanggung hidup diakhir jangka waktu [2].

$$
A_{x: n}=\left(\sum_{k=0}^{n-1} v_{k}^{k+1} p_{x} q_{x+k}\right)+v_{n}^{n} p_{x}
$$

keterangan:

$n \quad=$ Lama masa periode pertanggungan asuransi

$k \quad=$ Sisa masa pertanggungan asuransi

$v^{k+1} \quad=$ Faktor diskonto periode $(k+1)$

${ }_{k} p_{x} \quad=$ Peluang seseorang berusia $x$ tahun akan hidup sampai $k$ tahun

$q_{x+k} \quad=$ Peluang seseorang berusia $(x+k)$ tahun akan meninggal 1 tahun ke depan

$v^{n} \quad=$ Faktor diskonto pada periode $n$ tahun

${ }_{n} p_{x} \quad=$ Peluang seseorang berusia $x$ tahun akan hidup sampai $n$ tahun

$A_{x: n} \quad=$ Asuransi jiwa dwiguna seorang berusia $x$ dengan lama masa periode pertanggungan asuransi $n$ tahun

Anuitas merupakan suatu pembayaran secara berkelanjutan dilakukan setiap selang waktu tertentu dengan besar uang yang sama. Anuitas jiwa adalah anuitas pasti dengan serangkaian pembayaran dalam interval waktu (pembayaran bulanan, empat bulan, tahunan) yang dilakukan selama seseorang masih hidup. Pada penelitian ini anuitas jiwa yang digunakan dalam perhitungan yaitu anuitas jiwa diskret awal berjangka $n$ tahun [2].

$$
\ddot{a}_{x: n}=\sum_{k=0}^{n-1} v^{k}{ }_{k} p_{x}
$$

Premi merupakan sejumlah uang yang wajib dibayarkan oleh pemegang polis kepada perusahaan asuransi dengan cara yang telah ditentukan dan sekaligus menjadi syarat diperolehnya perlindungan asuransi [2]. Setiap orang yang mengasuransikan jiwanya, maka ia dikatakan telah menyetujui suatu kontrak secara tertulis antara dirinya dengan pihak perusahaan asuransi. Di dalam kontrak tersebut telah tertera besarnya premi yang harus dibayarkan beserta jadwal pembayarannya.

Dari faktor biayanya, premi dapat digolongkan menjadi dua yaitu premi bersih dan premi kotor. Premi bersih merupakan perhitungan premi tanpa memperlihatkan faktor biaya. Perhitungan premi bersih hanya menggunakan perkiraan tingkat suku bunga dan tingkat mortalita, sedangkan perkiraan tingkat biayanya tidak perlu digunakan. Premi kotor menambahkan biaya administrasi, gaji karyawan, komisi serta biaya-biaya operasional lainnya yang merupakan rahasia perusahaan sehingga besarnya turut diperhitungkan dalam penentuan tarif premi yang nantinya akan dibebankan kepada pemegang 
polis. Pada penelitian ini menggunakan perhitungan premi bersih dengan jangka waktu pembayaran diskret. Bentuk diskret dari premi tahunan untuk asuransi jiwa seumur hidup, yaitu [3]:

$$
P\left(A_{x: n}\right)=\frac{A_{x: n}}{\ddot{a}_{x: n}}
$$

\section{TINGKAT SUKU BUNGA}

Tingkat suku bunga terdiri atas dua jenis, yaitu bunga tunggal dan bunga majemuk. Bunga tunggal atau yang sering disebut dengan bunga sederhana, dihitung berdasarkan pada perbandingan pokok dengan jangka waktu investasinya. Sedangkan bunga majemuk merupakan perhitungan bunga yang besar pokok dan jangka investasinya ialah jumlahan antara besar pokok sebelumnya dengan besar bunga yang diperoleh [4].

Tingkat suku bunga (i) adalah rasio dari besar bunga yang diperoleh selama periode tertentu terhadap besarnya nilai pokok pada saat awal periode [5]. Nilai sekarang adalah investasi sebesar 1 yang akan terakumulasi menjadi $(i+1)$ pada akhir periode ke 1 [4]. Nilai sekarang pada periode $n$ juga bisa disebut dengan faktor diskonto yang dinotasikan dengan $v^{n}$, yaitu:

$$
v^{n}=\frac{1}{(i+1)^{n}}
$$

\section{CADANGAN PROSPEKTIF}

Perhitungan cadangan dapat dilakukan diantaranya menggunakan metode prospektif. Metode cadangan prospektif adalah perhitungan cadangan yang berorientasi pada pengeluaran di waktu yang akan datang. Perhitungan cadangan berdasarkan nilai sekarang dari semua pengeluaran di waktu yang akan datang, dikurangi dengan nilai sekarang total pendapatan di waktu yang akan datang untuk setiap pemegang polis [4]. Oleh karena itu cadangan bukanlah suatu aset atau bagian kekayaan perusahaan, melainkan kewajiban perusahaan atau dengan kata lain hutang perusahaan kepada para pemegang polis. Fungsi kerugian dari manfaat cadangan adalah [2]:

$$
\begin{aligned}
{ }_{k} L & =v^{(K(x)-k)+1}-P_{x} \ddot{a}_{\overline{(K(x)-k)+1}} \\
{ }_{k} V_{x} & =E\left[{ }_{k} L \mid K(x)=k, k+1, \ldots\right]
\end{aligned}
$$

Cadangan Prospektif didefinisikan sebagai selisih antara nilai sekarang aktuaria dari santunan yang akan datang dengan premi manfaat yang akan datang. Cadangan Prospektif untuk asuransi berjangka penuh dengan pembayaran premi tahunan dan pembayaran manfaat diakhir tahun [3].

$$
{ }_{k} V_{x}=A_{x+k}-P_{x} \ddot{a}_{x+k}
$$

Berdasarkan definisi cadangan prospektif, simbol beserta rumus untuk cadangan prospektif diskret dituliskan pada Tabel 1.

Tabel 1 Cadangan Prospektif Diskret

\begin{tabular}{lcc}
\hline \multicolumn{1}{c}{ Jenis Asuransi Jiwa } & $\begin{array}{c}\text { Notasi Aktuaria } \\
\text { Internasional }\end{array}$ & \multicolumn{1}{c}{ Persamaan Prospektif } \\
\hline $\begin{array}{l}\text { Dwiguna berjangka } n \\
\text { tahun }\end{array}$ & ${ }_{t} V\left(A_{x: n}\right)$ & $\left\{\begin{array}{cc}A_{x+t: \overline{n-t}}-P\left(A_{x: n}\right) \ddot{a}_{x+t \overline{n-t}} \\
1\end{array}\right.$ \\
$\begin{array}{l}\text { Dwiguna berjangka } n \\
\text { tahun, pembayaran } h \\
\text { tahun }\end{array}$ & ${ }_{t}^{h} V\left(A_{x: n}\right)$ \\
\hline
\end{tabular}




\section{METODE ILLINOIS}

Penentuan cadangan dengan metode Illinois terdapat persyaratan yang harus terpenuhi yaitu nilai premi bersih tahunan yang dibayarkan tertanggung lebih besar dari nilai premi bersih tahunan asuransi jiwa seumur hidup dengan jangka pembayaran 20 kali pembayaran pada usia yang sama. Metode Illinois menyatakan bahwa akhir jangka waktu pembayaran premi atau pada akhir jangka 20 kali pembayaran [4].

$$
{ }_{t}^{h} V\left(A_{x: n}\right) \quad ; h \geq 20
$$

Pada metode Illinois terdapat tiga nilai premi bersih yaitu:

1. $\alpha^{I}$ (premi bersih untuk pembayaran pertama),

2. $\beta^{I}$ (premi bersih untuk 19 kali pembayaran berikutnya), dan

3. $P^{I}$ (premi bersih untuk pembayaran seterusnya). dengan:

$$
\beta^{I}-\alpha^{I}={ }_{19} P_{x+1}-R \frac{C_{x}}{D_{x}}
$$

keterangan

$R=$ Santunan

$\frac{C_{x}}{D_{x}}=$ Premi berjangka satu tahun yang diperpanjang setiap tahunnya sampai waktu tertentu dengan usia tertanggung $x$ tahun

Polis dengan pembayaran premi $>20$ tahun, maka persamaan umum metode Illinois dapat dituliskan sebagai berikut:

$$
\alpha^{I}+\beta^{I} a_{x: 19 \mid}+P_{20 \mid n-20} \ddot{a}_{x}=P \ddot{a}_{x: n}
$$

Sedangkan polis dengan pembayaran premi $\leq 20$ tahun, maka persamaan umum metode Illinois dapat dituliskan sebagai berikut:

$$
\alpha^{I}+\beta^{I} a_{x: \overline{k-1}}=P \ddot{a}_{x: \bar{k}}, k=0,1,2, \ldots 20
$$

Metode Illinois didefinisikan sebagai berikut:

a. Cadangan akhir tahun ke- $t$ untuk asuransi jiwa dwiguna berjangka $h=20, n>h$ untuk seorang berusia $x$ :

$$
{ }_{t}^{h} V^{I}\left(A_{x: n}\right)= \begin{cases}A_{x+t: \overline{n-t}}-\beta^{I}\left(A_{x: n}\right) \ddot{a}_{x+t: \overline{h-t} t}, & t \leq h \\ A_{x+t: \overline{n-t}}, & h<t<n \\ 1, & t=n\end{cases}
$$

b. Cadangan akhir tahun ke- $t$ untuk asuransi jiwa dwiguna berjangka $n \leq 20$, untuk seorang berusia $x$ :

$$
{ }_{t}^{h} V^{I}\left(A_{x: n}\right)=\left\{\begin{array}{lc}
A_{x+t: \overline{n-t}}, & h<t<n \\
1, & t=n
\end{array}\right.
$$

c. Cadangan akhir tahun ke- $t$ untuk asuransi jiwa dwiguna berjangka $n>20,20<h<n$ untuk seorang berusia $x$ :

$$
{ }_{t}^{h} V^{I}\left(A_{x: n}\right)= \begin{cases}A_{x+t: \overline{n-t}}-\beta^{I}\left(A_{x: n}\right) \ddot{a}_{x+t: \overline{20-t} \mid}-{ }_{h} P\left(A_{x: n}\right)\left[{ }_{20-t \mid h-20} \ddot{a}_{x+t}\right], & t \leq 20 \\ A_{x+t: \overline{n-t} \mid}-{ }_{h} P\left(A_{x: n}\right) \ddot{a}_{x+t: h-t}, & 20<t \leq h \\ A_{x+t: \overline{n-t} t}, & h<t<n \\ 1, & \end{cases}
$$


d. Cadangan akhir tahun ke- $t$ untuk asuransi jiwa dwiguna berjangka $n>20$, untuk seorang berusia $x$ :

$$
{ }_{t}^{h} V^{I}\left(A_{x: n}\right)= \begin{cases}A_{x+t: \overline{n-t}}-\beta^{I}\left(A_{x: n}\right) \ddot{a}_{x+t: \overline{20-t} \mid}-P\left(A_{x: n}\right)[20-t \mid n-20 & \left.\ddot{a}_{x+t}\right], \\ A_{x+t: \overline{n-t} \mid}-P\left(A_{x: n}\right) \ddot{a}_{x+t: n-t}, & 20<t<n \\ 1, & t=n\end{cases}
$$

Dalam penyelesaian perhitungan cadangan metode Illinois ini, menggunakan bantuan aplikasi Microsoft Excel. Peluang kematian menggunakan Tabel Mortalita Indonesia tahun 2011. Jenis asuransi jiwa yang digunakan dalam penelitian ini adalah asuransi jiwa dwiguna berjangka $h$ tahun.

\section{APLIKASI NUMERIK}

Pada penelitian ini akan diberikan contoh kasus sebagai simulasi perhitungan cadangan premi asuransi untuk produk asuransi jiwa dwiguna berjangka dengan program yang akan digunakan adalah Microsoft Excel. Contoh kasus untuk seorang laki-laki berusia 20 tahun hendak mengikuti program asuransi jiwa dwiguna dengan lama masa pertanggungan asuransi 25 tahun dan jangka waktu pembayaran premi 20 kali pembayaran. Premi akan dibayarkan setiap awal periode selama tertanggung masih hidup dan besar santunan yang akan diterima ahli waris ketika tertanggung meninggal dunia adalah Rp100.000.000. Jenis asuransi yang dipilih adalah asuransi jiwa dwiguna dengan menggunakan Tabel Mortalita Indonesia tahun 2011 dan suku bunga $i=5,75 \%$.

\begin{tabular}{ccc} 
Tabel 2 Hasil Cadangan Prospektif dan Cadangan \\
\hline $\boldsymbol{T}$ & $\begin{array}{c}\text { Cadangan } \\
\text { Prospektif }\end{array}$ & $\begin{array}{c}\text { Cadangan } \\
\text { Illinois }\end{array}$ \\
\hline 1 & Rp2.009.279 & Rp1.522.035 \\
2 & Rp4.125.541 & Rp3.653.062 \\
3 & Rp6.355.439 & Rp5.898.539 \\
$\vdots$ & $\vdots$ & $\vdots$ \\
20 & Rp71.622.495 & Rp71.622.495 \\
21 & Rp75.703.615 & Rp75.703.615 \\
22 & Rp80.021.611 & Rp80.021.611 \\
23 & Rp84.592.655 & Rp84.592.655 \\
24 & Rp89.433.592 & Rp89.433.592 \\
25 & Rp100.000.000 & Rp100.000.000
\end{tabular}

Pada Tabel 2 dapat dilihat bahwa pada tahun ke-1 hingga tahun ke-19 nilai cadangan disesuaikan dengan metode Illinois lebih kecil daripada cadangan metode prospektif dan pada akhir jangka waktu 20 tahun nilai kedua cadangan bernilai sama. Nilai cadangan Prospektif yang diperoleh lebih besar daripada metode Illinois. Hal ini disebabkan cadangan Prospektif hanya menggunakan premi bersih tanpa mempertimbangkan biaya operasional. Biaya operasional bila tidak digunakan dalam perhitungan premi dapat mengakibatkan perushaan asuransi mengalami kerugian. Hal ini dikarenakan besar cadangan premi yang diperoleh tidak sesuai dengan perhitungan. Cadangan premi menggunakan metode Illinois dapat mengindari risiko tersebut. Pada tahun terakhir jangka asuransi, nilai cadangan Prospektif dan cadangan dengan metode Illinois bernilai sama dengan besarnya santunan yang akan diberikan.

\section{PENUTUP}

Nilai cadangan premi dengan metode Illinois menghasilkan cadangan yang lebih kecil dibandingkan dengan cadangan Prospektif. Hal ini sangat menguntungkan bagi pihak perusahaan. 
Perusahaan bisa menggunakan selisih uang pembayaran premi dengan cadangan yang harus disisihkan untuk kemudian diinvetasikan. Besarnya nilai cadangan yang diperoleh juga berguna bagi perusahaan asuransi jiwa untuk mempersiapkan dana santunan yang diberikan apabila terjadi klaim. Perhitungan cadangan dengan metode Illinois menggunakan premi bersih.

\section{DAFTAR PUSTAKA}

[1]. Salim A. Abbas. Asuransi dan Manajeman Resiko. Jakarta: Grafindo Persada;2007.

[2]. Effendie, A. R. Matematika Aktuaria . Jakarta: Universitas Terbuka;2010.

[3]. Bowers, N. L., Geerber, H. U., Hickman, J. C., Jones, D. A., \& Nesbitt, C. J. Actuarial Mathematics. Schaumhurg: Society Of Actuaries; 1997.

[4]. Futami, T. Matematika Asuransi Jiwa Bagian I. Tokyo: Incorporated Foundation Oriental Life Insurance Cultural Development Center;1993.

[5]. Achdijad, Didi. Prinsip-Prinsip Aktuaria pada Asuransi Jiwa. Jakarta: Gunadarma;1990.

$\begin{array}{ll}\text { DWI AYU LESTARI } & \begin{array}{l}\text { Jurusan Matematika FMIPA UNTAN Pontianak } \\ \text { dwiayulestari503@ gmail.com }\end{array} \\ \text { NEVA SATYAHADEWI } & \begin{array}{l}\text { Jurusan Matematika FMIPA UNTAN Pontianak, } \\ \text { neva.satya @math.untan.ac.id } \\ \text { : Jurusan Matematika FMIPA UNTAN Pontianak, } \\ \text { hendra.perdana@math.untan.ac.id }\end{array}\end{array}$

